\title{
Hashimoto's thyroiditis, nodular goiter or follicular adenoma combined with papillary thyroid carcinoma play protective role in patients
}

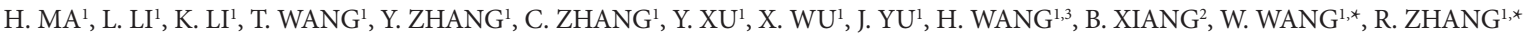 \\ ${ }^{1}$ Department of Pathology, Affiliated Hospital of Jining Medical University, Jining, Shandong 272029, China; ${ }^{2}$ Cancer Research Institute, Xiangya \\ School of Medicine, Central South University, Changsha 410078, China; ${ }^{3}$ Department of Pathology, Traditional Chinese Medicine Hospital of \\ Juye County, Heze, Shandong 274900, China
}

*Correspondence: wangwei1985@csu.edu.cn, hzzhang_1964@163.com

Received April 28, 2017 / Accepted June 14, 2017

\begin{abstract}
Papillary thyroid carcinoma (PTC) is often combined with other types of thyroid disease, such as Hashimoto's thyroiditis (HT), nodular goiter (NG), follicular adenoma (FA) and other types. However, the function of these diseases in PTC tumorigenesis and development is not well understood. In this research, 563 PTC patients were recruited and divided into two groups according to pathological diagnosis, namely simple PTC (PTC) and PTC combined with other thyroid diseases (PTC+). Clinicopathological characteristics and BRAF ${ }^{\mathrm{V} 600 \mathrm{E}}$ mutation status were compared between PTC and PTC+. Our data showed that there was a statistically significant difference in gender $(\mathrm{p}=0.007)$, tumor diameter $(5 \mathrm{~mm}, \mathrm{p}=0.012 ; 1 \mathrm{~cm}, \mathrm{p}=0.042)$, lymph node metastasis $(\mathrm{p}=0.000)$ and BRAFV600E mutation status $(\mathrm{p}=0.001)$ between PTC and PTC + PTC+ patients have lower lymph node metastasis rate, even if PTC nodule diameter is larger than $5 \mathrm{~mm}(\mathrm{p}=0.005)$ or $\geq 1 \mathrm{~cm}(\mathrm{p}=0.049)$ or $\mathrm{BRAF}^{\mathrm{V} 600 \mathrm{E}}$ is mutated $(\mathrm{p}=0.001$ ). In conclusion, our study suggests that $\mathrm{HT}, \mathrm{NG}$ and $\mathrm{FA}$, are protective factors of PTC patients, and PTC+ patients have lower lymph node metastasis and $\mathrm{BRAF}^{\mathrm{V} 600 \mathrm{E}}$ mutation rate compared with simple PTC patients.
\end{abstract}

Key words: papillary thyroid carcinoma, combined papillary thyroid carcinoma, protective effect, BRAF

Thyroid cancer is one of the most common endocrine malignancies in the world, the incidence is still rising [1]. Thyroid cancer is the fifth highest incidence of cancer in the world and the incidence rate accounts for about $6 \%$ of all women cancers $[2,3]$. PTC is the most frequent type of thyroid cancer, which is originated from follicular epithelial cells, and accounts for $75-85 \%$ malignant thyroid cancer $[4,5]$. Despite the high incidence of PTC, early detection and treatment has achieved excellent prognosis, with a five year survival rate of $95 \%[6,7]$ and a ten year survival rate of $80-95 \%$ [8].

PTC is often combined with other types of thyroid disease, such as HT, NG and FA, etc, while the function of these diseases in PTC tumorigenesis and development is not well understood. Some studies have shown that HT may be a protective factor in PTC, and is negatively correlated with $\mathrm{BRAF}^{\mathrm{V} 600 \mathrm{E}}$ mutation, extra thyroid proliferation and lymph node metastasis. Moreover, even if $\mathrm{BRAF}^{\mathrm{V} 600 \mathrm{E}}$ is mutated, PTC patients accompanied with HT have less extrathyroidal extension and lymph node metastasis $[9,10]$.

$\mathrm{BRAF}^{\mathrm{V} 600 \mathrm{E}}$ mutation is the most common genetic variants of PTC. Mutation of BRAF gene T1799A results in amino acid substitution of glutamic acid (E) by valine (V). BRAF plays an important role in cell proliferation, differentiation and apoptosis. BRAF ${ }^{\mathrm{V} 600 \mathrm{E}}$ mutation can continuously promote the proliferation and differentiation of thyroid cells through activating RAF-MEK-ERK signaling pathway [11, $12]$, leading to a more malignant phenotype of PTC $[13,14]$. In addition, $\mathrm{BRAF}^{\mathrm{V} 600 \mathrm{E}}$ mutations were shown to be associated with extrathyroidal extension, lymph node metastasis, distant metastasis, TNM stage, tumor recurrence and poor prognosis of PTC [15-18].

In this study, the 563 PTC patients were divided into two groups (PTC and PTC+) according to whether or not accompanied with other types of thyroid disease, and the $\mathrm{BRAF}^{\mathrm{V} 600 \mathrm{E}}$ mutation status was tested in all samples. The clinicopathological characteristics and $\mathrm{BRAF}^{\mathrm{V} 600 \mathrm{E}}$ mutation status were analyzed between PTC and PTC+.

\section{Patients and methods}

Patient characteristics. A total of 563 cases of surgical specimens were collected from Affiliated Hospital of Jining Medical University from July 2015 to March 2017, all patients were diagnosed with PTC by pathology. The gender ratio is 
1:6.5, including 75 males (13.3\%) and 488 females $(86.7 \%)$, and the average age is 44.6 years ( $44.6 \pm 11.56$ years). Among all the cases, $198 \mathrm{PTC}+$ cases were recognized, including 85 $\mathrm{PTC}+\mathrm{HT}$ cases, $79 \mathrm{PTC}+\mathrm{NG}$ cases, $18 \mathrm{PTC}+\mathrm{FA}$ cases and 16 PTC+others cases. BRAF ${ }^{\mathrm{V} 600 \mathrm{E}}$ mutation was tested in all patients. The study was approved by the ethics committee of Jining Medical University. Each patient has signed an informed consent form.

DNA extraction and $\mathrm{BRAF}^{\mathrm{V} 600 \mathrm{E}}$ mutation detection. All isolated thyroid tissues were fixed with $10 \%$ neutral formalin within 30 minutes, followed by dehydration, transparency, wax dipping and embedding. The paraffin-embedded tissue was cut to $4 \mu \mathrm{m}$ thickness and 3-4 slices were used for DNA extraction. Steps are performed in accordance with the FFPE sample DNA kit following the instructions (Amoy Diagnostics Co., Ltd., Xiamen, China), in accordance with the human BRAF gene V600E mutation detection kit (fluorescence PCR method) instructions for PCR detection, and positive interpretation (Amoy Diagnostics Co., Ltd., Xiamen, China).

Statistical analysis. All statistical analyses were performed using SPSS software (SPSS, version 19.0; SPSS; Chicago, IL, USA). Count data were analyzed by $\chi^{2}$ test, statistical difference is defined as $\mathrm{p}<0.05$.

\section{Results}

Comparison of pathological features between PTC and PTC+. Compared with PTC patients, the incidence of PTC+ tends to be higher in women $(p=0.007)$; the diameter of the tumor tends to be $\leq 5 \mathrm{~mm}(\mathrm{p}=0.012)$ or $<1 \mathrm{~cm}(\mathrm{p}=0.042)$; $\mathrm{PTC}+$ has low local lymph node metastasis rate $(\mathrm{p}=0.000)$ and low mutation rate of $\operatorname{BRAF}^{\mathrm{V} 600 \mathrm{E}}(\mathrm{p}=0.001)$ (Table 1$)$. There were differences in gender $(\mathrm{p}=0.007)$, tumor diameter ( $5 \mathrm{~mm}, \mathrm{p}=0.012 ; 1 \mathrm{~cm}, \mathrm{p}=0.042$ ), lymph node metastasis $(p=0.000)$ and BRAF $^{\mathrm{V} 600 \mathrm{E}}$ mutation status $(\mathrm{p}=0.001)$ for PTC+ in comparison with PTC, while the age has no association with PTC and PTC+.

The PTC+ group was further subdivided into PTC+HT, PTC+NG, PTC+FA and PTC+others. Compared with the PTC group: age, no difference; gender, $\mathrm{PTC}+\mathrm{TH}$ is more likely to occur in women $(\mathrm{p}=0.031)$, there was no significant difference between the PTC and other PTC+ groups for gender; local lymph node metastasis, compared with the PTC group, the lymph node metastasis rate of PTC $+\mathrm{HT}$ $(\mathrm{p}=0.013), \mathrm{PTC}+\mathrm{NG}(\mathrm{p}=0.000)$ and PTC+FA $(\mathrm{p}=0.04)$ was lower, the difference was statistically significant; $\mathrm{BRAF}^{\mathrm{V} 600 \mathrm{E}}$ mutation, the mutation rate of PTC $+\mathrm{HT}(\mathrm{p}=0.025)$ and PTC+FA $(p=0.01)$ was lower than in the PTC group (Table 1).

PTC+ was associated with malignant pathological features in patients with larger tumor diameter and positive BRAF mutation. The protective effect of $\mathrm{PTC}+$ in patients with small tumor diameter $(\leq 5 \mathrm{~mm}$ or $<1 \mathrm{~cm})$ is evident. There were significant differences in lymph node metastasis $(\leq 5 \mathrm{~mm}, \mathrm{p}=0.002 ;<1 \mathrm{~cm}, \mathrm{p}=0.000)$ and $\mathrm{BRAF}^{\mathrm{V} 600 \mathrm{E}}$ mutation status $(\leq 5 \mathrm{~mm}, \mathrm{p}=0.001 ;<1 \mathrm{~cm}, \mathrm{p}=0.000)$ for PTC+ in comparison with PTC (Table S1, S2).

Further statistical analysis revealed that PTC+ also has protective effect in PTC patients with malignant features, such as larger tumor diameter or positive BRAF mutation. For patients with diameter $>5 \mathrm{~mm}$, PTC+ has lower lymph node metastasis rate $(\mathrm{p}=0.005)$ and lower $\mathrm{BRAF}^{\mathrm{V} 600 \mathrm{E}}$ mutation rate (Fisher test, $\mathrm{p}=0.047$ ) than that of PTC (Table 2). PTC+ patients with tumor diameter $\geq 1 \mathrm{~cm}$ are only associated with lower lymph node metastasis rate $(\mathrm{p}=0.049)$ than that of PTC (Table 3). Similarly, patients with BRAF mutation were also analyzed statistically in the two groups, PTC+ is also more likely to occur in women with BRAF mutations $(p=0.026)$, and PTC+ is associated with lower local lymph node metastasis $(\mathrm{p}=0.001)$ than that of PTC (Table 4).

Table 1. Clinical pathological characteristics between PTC and PTC+, $\mathrm{n}=563$

\begin{tabular}{|c|c|c|c|c|c|c|}
\hline & $\begin{array}{c}\text { PTC }^{a} \\
n=365\end{array}$ & & & & & Total \\
\hline & $(\%)$ & $\begin{array}{c}H^{1} \\
n=85\end{array}$ & $\begin{array}{c}N^{2} \\
n=79\end{array}$ & $\begin{array}{c}\mathrm{FA}^{3} \\
\mathrm{n}=18\end{array}$ & $\begin{array}{c}\mathrm{Ot}^{4} \\
\mathrm{n}=16\end{array}$ & \\
\hline Age, yrs & & & & & & \\
\hline$<45$ & $180(49)$ & $40(47)$ & $33(42)$ & $7(39)$ & $7(44)$ & 267 \\
\hline$\geq 45$ & $185(51)$ & $45(53)$ & $46(58)$ & $11(61)$ & $9(56)$ & 296 \\
\hline$\chi^{2}$ & $1.488^{\mathrm{ab}}$ & $0.14^{\mathrm{a} 1}$ & $1.48^{\mathrm{a} 2}$ & $0.746^{\mathrm{a} 3}$ & $0.19^{\mathrm{a} 4}$ & \\
\hline p-value & 0.223 & 0.708 & 0.224 & 0.388 & 0.663 & \\
\hline Gender & & & & & & \\
\hline female & $306(84)$ & 79 (93) & $71(90)$ & $17(94)$ & $15(94)$ & 488 \\
\hline male & $59(16)$ & $6(7)$ & $8(10)$ & $1(6)$ & $1(6)$ & 75 \\
\hline$\chi^{2}$ & $7.264^{\mathrm{ab}}$ & $4.626^{\mathrm{al}}$ & $1.848^{\mathrm{a} 2}$ & $1.461^{\mathrm{a} 3}$ & $1.136^{\mathrm{a} 4}$ & \\
\hline p-value & 0.007 & 0.031 & 0.174 & 0.227 & 0.287 & \\
\hline Diameter & & & & & & \\
\hline$\leq 5 \mathrm{~mm}$ & $60(16)$ & $21(25)$ & $21(27)$ & $3(17)$ & $5(31)$ & 110 \\
\hline$>5 \mathrm{~mm}$ & $305(84)$ & $64(75)$ & $58(73)$ & $15(83)$ & $11(69)$ & 453 \\
\hline$\chi^{2}$ & $6.344^{\mathrm{ab}}$ & $3.193^{\mathrm{al}}$ & $4.48^{\mathrm{a} 2}$ & $0.001^{\mathrm{a} 3}$ & $2.377^{\mathrm{a} 4}$ & \\
\hline p-value & 0.012 & 0.074 & 0.034 & 0.980 & 0.123 & \\
\hline$<1 \mathrm{~cm}$ & $150(41)$ & $41(48)$ & $43(54)$ & $9(50)$ & $6(38)$ & 249 \\
\hline$\geq 1 \mathrm{~cm}$ & 215 (59) & $44(52)$ & $36(48)$ & $9(50)$ & $10(62)$ & 314 \\
\hline$\chi^{2}$ & $4.126^{\mathrm{ab}}$ & $1.439^{\mathrm{al}}$ & $4.699^{\mathrm{a} 2}$ & $0.560^{\mathrm{a} 3}$ & $0.082^{\mathrm{a} 4}$ & \\
\hline p-value & 0.042 & 0.230 & 0.030 & 0.454 & 0.775 & \\
\hline Lymph nod & e metastas & & & & & \\
\hline No & $173(47)$ & $53(62)$ & $55(65)$ & $13(72)$ & $10(63)$ & 304 \\
\hline Yes & $192(53)$ & $32(38)$ & $24(35)$ & $5(28)$ & $6(37)$ & 259 \\
\hline$\chi^{2}$ & $18.195^{\mathrm{ab}}$ & $6.169^{\mathrm{al}}$ & $12.839^{\mathrm{a} 2}$ & $4.232^{\mathrm{a} 3}$ & $1.401^{\mathrm{a} 4}$ & \\
\hline p-value & 0.000 & 0.013 & 0.000 & 0.040 & 0.237 & \\
\hline $\mathrm{BRAF}^{\mathrm{V} 600 \mathrm{E}}$ & & & & & & \\
\hline WT & $57(16)$ & $22(26)$ & $19(24)$ & $7(39)$ & $5(31)$ & 110 \\
\hline Mut & $308(84)$ & $63(74)$ & $60(76)$ & $11(61)$ & $11(69)$ & 453 \\
\hline$\chi^{2}$ & $10.154^{\mathrm{ab}}$ & $5.02^{\mathrm{al}}$ & $3.256^{\mathrm{a} 2}$ & $6.675^{\mathrm{a} 3}$ & $2.75^{\mathrm{a} 4}$ & \\
\hline p-value & 0.001 & 0.025 & 0.074 & 0.010 & 0.097 & \\
\hline
\end{tabular}


Table 2. Clinical pathological characteristics between PTC and PTC+, tumor diameter $>5 \mathrm{~mm}, \mathrm{n}=453$

\begin{tabular}{lccccc}
\hline & $\begin{array}{c}\text { PTC } \\
\mathbf{N}=\mathbf{3 0 5} \\
(\mathbf{\%})\end{array}$ & $\begin{array}{c}\text { PTC+ } \\
\mathbf{N = 1 4 8} \\
(\mathbf{\%})\end{array}$ & Total & $\boldsymbol{\chi}^{\mathbf{2}}$ & p-value \\
\hline Age & & & & & \\
$<45$ yrs & $144(47)$ & $68(46)$ & 212 & 0.064 & 0.800 \\
$\geq 45$ yrs & $161(53)$ & $80(54)$ & 241 & & \\
Gender & & & & & \\
female & $255(84)$ & $137(93)$ & 392 & 6.867 & $\mathbf{0 . 0 0 9}$ \\
male & $50(16)$ & $11(7)$ & 61 & & \\
Lymph node metastasis & & & & \\
No & $132(43)$ & $85(57)$ & 217 & 7.999 & $\mathbf{0 . 0 0 5}$ \\
Yes & $173(57)$ & $63(37)$ & 236 & & \\
BRAF & & & & & \\
WT & $45(15)$ & $32(22)$ & 77 & 3.331 & 0.068 \\
Mut & $260(85)$ & $116(78)$ & 376 & Fisher & $\mathbf{0 . 0 4 7}$ \\
\hline
\end{tabular}

Table 3. Clinical pathological characteristics between PTC and PTC+, tumor diameter $\geq 1 \mathrm{~cm}, \mathrm{n}=314$

\begin{tabular}{|c|c|c|c|c|c|}
\hline & $\begin{array}{c}\text { PTC } \\
\text { N=215 } \\
(\%)\end{array}$ & $\begin{array}{c}\text { PTC+ } \\
\text { N=99 } \\
(\%)\end{array}$ & Total & $\chi^{2}$ & p-value \\
\hline \multicolumn{6}{|l|}{ Age } \\
\hline$<45$ yrs & $106(49)$ & $44(44)$ & 150 & \multirow{2}{*}{0.641} & \multirow{2}{*}{0.423} \\
\hline$\geq 45$ yrs & $109(51)$ & $55(56)$ & 144 & & \\
\hline \multicolumn{6}{|l|}{ Gender } \\
\hline female & $184(86)$ & $92(93)$ & 276 & \multirow{2}{*}{3.441} & \multirow{2}{*}{0.064} \\
\hline male & $31(14)$ & $7(7)$ & 38 & & \\
\hline \multicolumn{6}{|c|}{ Lymph node metastasis } \\
\hline No & $79(37)$ & $48(48)$ & 127 & \multirow{2}{*}{3.879} & \multirow{2}{*}{0.049} \\
\hline Yes & $136(63)$ & $51(52)$ & 187 & & \\
\hline \multicolumn{6}{|l|}{$\mathrm{BRAF}^{\mathrm{V} 600 \mathrm{E}}$} \\
\hline WT & $33(15)$ & $22(22)$ & 55 & \multirow{2}{*}{2.217} & \multirow{2}{*}{0.137} \\
\hline Mut & $182(85)$ & 77 (78) & 259 & & \\
\hline
\end{tabular}

Table 4. Clinical pathological characteristics between PTC and PTC+, BRAF $^{\text {V600E }}$ status is mutation, $n=453$

\begin{tabular}{|c|c|c|c|c|c|}
\hline & $\begin{array}{c}\text { PTC } \\
\text { n=308 } \\
(\%)\end{array}$ & $\begin{array}{c}\text { PTC+ } \\
\text { n=145 } \\
(\%)\end{array}$ & Total & $\chi^{2}$ & p-value \\
\hline \multicolumn{6}{|l|}{ Age } \\
\hline$<45 \mathrm{yr}$ & $145(47)$ & $64(44)$ & 209 & \multirow{2}{*}{0.343} & \multirow{2}{*}{0.558} \\
\hline$\geq 45 \mathrm{yr}$ & $163(53)$ & $81(56)$ & 244 & & \\
\hline \multicolumn{6}{|l|}{ Gender } \\
\hline female & $259(84)$ & $133(92)$ & 392 & \multirow{2}{*}{4.93} & \multirow{2}{*}{0.026} \\
\hline male & 49 (16) & $12(8)$ & 61 & & \\
\hline \multicolumn{6}{|l|}{ Diameter } \\
\hline$\leq 5 \mathrm{~mm}$ & $48(16)$ & $29(20)$ & 77 & \multirow{2}{*}{1.362} & \multirow{2}{*}{0.243} \\
\hline$>5 \mathrm{~mm}$ & $260(84)$ & $116(80)$ & 376 & & \\
\hline$<1 \mathrm{~cm}$ & 126 & 68 & 194 & \multirow{2}{*}{1.443} & \multirow{2}{*}{0.230} \\
\hline$\geq 1 \mathrm{~cm}$ & 182 & 77 & 259 & & \\
\hline \multicolumn{6}{|c|}{ Lymph node metastasis } \\
\hline No & $146(47)$ & $93(64)$ & 239 & \multirow{2}{*}{11.078} & \multirow{2}{*}{0.001} \\
\hline Yes & $162(53)$ & $52(36)$ & 214 & & \\
\hline
\end{tabular}

For BRAF-WT patients, there were differences in lymph node metastasis $(\mathrm{p}=0.010)$ and $\mathrm{BRAF}^{\mathrm{V} 600 \mathrm{E}}$ mutation status ( $\leq 5 \mathrm{~mm}, \mathrm{p}=0.034 ;<1 \mathrm{~cm}, \mathrm{p}=0.086$ ) for $\mathrm{PTC}+$ in comparison with PTC (Table S3).

\section{Discussion}

It is well known that lymph node metastasis is closely related to the malignant progression of PTC patients. In addition, $\mathrm{BRAF}^{\mathrm{V} 600 \mathrm{E}}$ mutation has a role in thyroid tumorigenesis, tumor progression, recurrence, and is associated with decreased disease-free survival in PTC [19-22], conferring to PTC a more aggressive clinical behavior [13, 14]. Papillary thyroid microcarcinoma (PTMC) is a low-risk type of PTC [23], which is defined by the diameter $\leq 1 \mathrm{~cm}$ and has no local lymph node and/or distant organ metastasis and extra thyroid invasion. PTMC usually has an excellent prognosis [24], postoperative recurrence of PTMC is not reduced by total thyroidectomy. Non-total thyroidectomy is also a good choice for treatment of PTMC patients [25].

In our study, we found that PTC+, especially in combination with HT, NG and FA, were associated with low lymph node metastasis and BRAF mutation rate in patients. Thyroid cancer is usually combined with infiltration of inflammatory cells, including lymphocytes, macrophages and mast cells, but contribution of these cells in the pathogenesis of cancer and the mechanism is not fully understood. Some studies have shown that $\mathrm{HT}$ is negatively associated with BRAF $\mathrm{V}^{\mathrm{V} 600 \mathrm{E}}$ mutation, extrathyroidal extension and lymph node metastasis. Moreover, even if there is a BRAF ${ }^{\mathrm{V} 600 \mathrm{E}}$ mutation, HT can also inhibit the proliferation of thyroid and lymph node metastasis $[9,10]$. Our data support that HT is a protective factor of PTC. In addition, Ugolini et al [26] found that compared to PTC, the lymphocyte infiltration of poorly differentiated and undifferentiated thyroid carcinoma with poor prognosis was significantly lower, suggesting that inflammatory cells play a protective role in thyroid cancer. The occurrence of chronic lymphocytic thyroiditis in patients with PTC has a relatively good prognosis [27]. However, some scholars believe that these inflammatory reactions promote the occurrence of PTC, and that HT is an early lesion of thyroid cancer. Okayasu et al [28] found that the degree of lymphocytic infiltration in patients with papillary thyroid carcinoma was significantly higher than that in patients with benign thyroid lesions. Pasquale et al [29] found that patients with HT during a 16-year period yielded 33 thyroid carcinomas, of which PTC was 30 cases, suggesting that HT leads to PTC. Inflammatory microenvironment is an essential component of all tumors. A few studies support the concept that the lymphocytic infiltration counteracts tumor progression $[30,31]$. In a more recent study, the final effect of myeloid cell infiltration of the tumor depends on the balance between tumor-antagonizing and tumor-promoting actions [32]. In our study, HT combined with PTC can reduce the local lymph node metastasis and 
BRAF mutation rate in patients; therefore, we suggest that concurrent HT is a protective factor in patients with PTC.

Our study also found that PTC+NG was negatively associated with local lymph node metastasis, and was approximately associated with low BRAF ${ }^{\mathrm{V} 600 \mathrm{E}}$ mutation rate $(\mathrm{p}=0.074)$. NG is a common pathology of the thyroid gland, and varies in incidence in different parts of the world [33]. The incidence of thyroid cancer in multinodular goiter is estimated to be 5-10\% [34]. The relationship with PTC is also controversial. Compared to PTC, the PTC+NG tumor volume is smaller and the lymph node metastasis rate is lower. Our study found that NG plays a protective role in PTC.

Follicular adenoma is the major subtype of thyroid adenoma. Thyroid adenoma is originated in thyroid follicular cells with a non-enveloped and vascular invasion, tumor differentiation, and benign follicular capsule. The incidence may be related to the metabolism of iodine, estrogen, dietary habits, and geographical location, environment and heredity factors. However, there is also controversy about whether thyroid follicular adenoma causes PTC. Our study showed FA+PTC to be in negative correlation with local lymph node metastasis and $\mathrm{BRAF}^{\mathrm{V} 600 \mathrm{E}}$ mutation rate in patients. It is suggested that FA has also a protective mechanism for PTC.

In summary, our study shows that HT, NG or FA combined with PTC has a protective mechanism in PTC patients, can decrease the PTC local lymph node metastasis and BRAF ${ }^{\mathrm{V} 600 \mathrm{E}}$ mutation rate. It is of great significance to elucidate the function of PTC accompanying disease for the treatment of patients with PTC, but the specific mechanism needs further study.

Supplementary information is available in the online version of the paper.

Acknowledgements: This research was supported by The Natural Science Foundation of Shandong Province, China (ZR2016HQ28); Science and Technology Development Project of Jining (2016-5628), The PhD Research Foundation Affiliated Hospital of Jining Medical University (2016-BS-002); The cultivation project of the National Natural Science Foundation of Jining Medical University (JYP201731); Research support fund for young teachers of Jining Medical University (JY2017FS007); Nursery Project of Affiliated Hospital of Jining Medical University (MP-2016-017; MP-2016020); The National Natural Science Foundation of China (81372304, 81572667, 81772902), the National "111" Project (Project \#111-212), The Natural Science Foundation of Hunan Province, China (2018JJ1040); Research project of Jining Medical University (JY2013KJ046).

\section{References}

[1] PELlEGRiti G, FRASCA F, REGALbUTO C, SQUATRITO S, VIGNERI R. Worldwide increasing incidence of thyroid cancer: update on epidemiology and risk factors. J Cancer Epidemiol 2013; 2013:965212. https://doi. org/10.1155/2013/965212
[2] TORRE L A, BRAY F, SIEGEL RL, FERLAY J, LORTETTIEULENT J et al. Global cancer statistics. 2012. CA Cancer J Clin 2015; 65: 87-108. https://doi.org/10.3322/caac.21262

[3] SIEGEL RL, MILLER KD, JEMAL A. Cancer statistics. 2015. CA Cancer J Clin 2015; 65: 5-29. https://doi.org/10.3322/ caac. 21254

[4] KEBEBEW E, WENG J, BAUER J, RANVIER G, CLARK OH et al. The prevalence and prognostic value of BRAF mutation in thyroid cancer. Ann Surg 2007; 246: 466-470. https://doi. org/10.1097/SLA.0b013e318148563d

[5] XING M, TUFANO RP, TUFARO AP, BASARIA S, EWERTZ $M$ et al. Detection of BRAF mutation on fine needle aspiration biopsy specimens: a new diagnostic tool for papillary thyroid cancer. J Clin Endocrinol Metab 2004; 89: 28672872. https://doi.org/10.1210/jc.2003-032050

[6] MARKOVINA S, GRIGSBY PW, SCHWARZ JK, DEWEES T, MOLEY JF et al. Treatment approach. surveillance. and outcome of well-differentiated thyroid cancer in childhood and adolescence. Thyroid 2014; 24: 1121-1126. https://doi. org/10.1089/thy.2013.0297

[7] SU X, JIANG X, XU X, WANG W, TENG X et al. Diagnostic value of BRAF (V600E)-mutation analysis in fine-needle aspiration of thyroid nodules: a meta-analysis. Onco Targets Ther 2016; 9: 2495-2509. https://doi.org/10.2147/OTT.S101800

[8] BILIMORIA KY, BENTREM DJ, KO CY, STEWART AK, WINCHESTER DP et al. Extent of surgery affects survival for papillary thyroid cancer. Ann Surg 2007; 246: 375-381. https://doi.org/10.1097/SLA.0b013e31814697d9

[9] ZENG RC, JIN LP, CHEN ED, DONG SY, CAI YF et al. Potential relationship between Hashimoto's thyroiditis and BRAF(V600E) mutation status in papillary thyroid cancer. Head Neck 2016; 38 Suppl 1:E1019-1025. https://doi. org/10.1002/hed.24149

[10] KIM SJ, MYONG JP, JEE HG, CHAI YJ, CHOI JY et al. Combined effect of Hashimoto's thyroiditis and $\mathrm{BRAF}(\mathrm{V} 600 \mathrm{E})$ mutation status on aggressiveness in papillary thyroid cancer. Head Neck 2016; 38: 95-101. https:// doi.org/10.1002/hed.23854

[11] PEYSSONNAUX C, EYCHENE A. The Raf/MEK/ERK pathway: new concepts of activation. Biol Cell 2001; 93: 53-62.

[12] HILGER RA, SCHEULEN ME, STRUMBERG D. The RasRaf-MEK-ERK pathway in the treatment of cancer. Onkologie 2002; 25: 511-518. https://doi.org/10.1016/S02484900(01)01125-X

[13] COOPER DS, DOHERTY GM, HAUGEN BR, KLOOS RT, LEE SL et al. Management guidelines for patients with thyroid nodules and differentiated thyroid cancer. Thyroid 2006; 16: 109-142. https://doi.org/10.1089/thy.2006.16.109

[14] NIKIFOROV YE, OHORI NP, HODAK SP, CARTY SE, LEBEAU SO et al. Impact of mutational testing on the diagnosis and management of patients with cytologically indeterminate thyroid nodules: a prospective analysis of 1056 FNA samples. J Clin Endocrinol Metab 2011; 96: 3390-3397. https://doi.org/10.1210/jc.2011-1469

[15] BENTZ BG, MILLER BT, HOLDEN JA, ROWE LR, BENTZ JS. B-RAF V600E mutational analysis of fine needle aspirates correlates with diagnosis of thyroid nodules. Otolaryngol Head Neck Surg 2009; 140: 709-714. https://doi. org/10.1016/j.otohns.2009.01.007 
[16] NAKAYAMA H. YOSHIDA A. NAKAMURA Y. HAYASHI H. MIYAGI Y. et al. Clinical significance of BRAF (V600E) mutation and Ki-67 labeling index in papillary thyroid carcinomas. Anticancer Res 2007; 27: 3645-3649.

[17] NIKIFOROVA MN, KIMURA ET, GANDHI M, BIDDINGER PW, KNAUF JA et al. BRAF mutations in thyroid tumors are restricted to papillary carcinomas and anaplastic or poorly differentiated carcinomas arising from papillary carcinomas. J Clin Endocrinol Metab 2003; 88: 5399-5404. https://doi.org/10.1210/jc.2003-030838

[18] RIESCO-EIZAGUIRRE G, GUTIERREZ-MARTINEZ P, GARCIA-CABEZAS MA, Nistal M, Santisteban P. The oncogene BRAF V600E is associated with a high risk of recurrence and less differentiated papillary thyroid carcinoma due to the impairment of Na+/I- targeting to the membrane. Endocr Relat Cancer 2006; 13: 257-269. https://doi. org/10.1677/erc.1.01119

[19] PARK SJ, SUN JY, HONG K, KWAK JY, KIM EK et al. Application of BRAF. NRAS. KRAS mutations as markers for the detection of papillary thyroid cancer from FNAB specimens by pyrosequencing analysis. Clin Chem Lab Med 2013; 51: 1673-1680. https://doi.org/10.1515/cclm-2012-0375

[20] FRASER S, GO C, ANISS A, SIDHU S, DELBRIDGE L et al. BRAF(V600E) Mutation is Associated with Decreased Disease-Free Survival in Papillary Thyroid Cancer. World J Surg 2016; 40: 1618-1624. https://doi.org/10.1007/s00268016-3534-X

[21] XING M, ALZAHRANI AS, CARSON KA, SHONG YK, KIM T Y et al. Association between BRAF V600E mutation and recurrence of papillary thyroid cancer. J Clin Oncol 2015; 33: 42-50. https://doi.org/10.1200/JCO.2014.56.8253

[22] CHEN Y, SADOW PM, SUH H, LEE K E, CHOI J Y et al. BRAF(V600E) Is Correlated with Recurrence of Papillary Thyroid Microcarcinoma: A Systematic Review. Multi-Institutional Primary Data Analysis. and Meta-Analysis. Thyroid 2016; 26: 248-255. https://doi.org/10.1089/thy.2015.0391

[23] ITO Y, MIYAUCHI A, ODA H. Low-risk papillary microcarcinoma of the thyroid: A review of active surveillance trials. Eur J Surg Oncol 2017. https://doi.org/10.1016/j. ejso.2017.03.004

[24] PLZAK J, ASTL J, PSYCHOGIOS G, ZENK J, LASTUVKA $\mathrm{P}$ et al. [Current treatment strategies for papillary thyroid microcarcinoma]. HNO 2013; 61: 300-305. https://doi. org/10.1007/s00106-013-2679-2
[25] YI D, SONG P, HUANG T, TANG X, SANG J. A metaanalysis on the effect of operation modes on the recurrence of papillary thyroid microcarcinoma. Oncotarget 2017; 8: 7148-7156. https://doi.org/10.18632/oncotarget.12698

[26] UGOLINI C, BASOLO F, PROIETTI A, VITTI P, ELISEI $\mathrm{R}$ et al. Lymphocyte and immature dendritic cell infiltrates in differentiated. poorly differentiated. and undifferentiated thyroid carcinoma. Thyroid 2007; 17: 389-393. https://doi. org/10.1089/thy.2006.0306

[27] KEBEBEW E, TRESELER PA, ITUARTE PH, CLARK OH. Coexisting chronic lymphocytic thyroiditis and papillary thyroid cancer revisited. World J Surg 2001; 25: 632-637. https://doi.org/10.1007/s002680020165

[28] OKAYASU I. The Relationship of Lymphocytic Thyroiditis to the Development of Thyroid Carcinoma. Endocr Pathol 1997; 8(3): 225-230.

[29] DI PASQUALE M, ROTHSTEIN JL, PALAZZO JP. Pathologic features of Hashimoto's-associated papillary thyroid carcinomas. Hum Pathol 2001; 32: 24-30. https://doi. org/10.1053/hupa.2001.21138

[30] LOH KC, GREENSPAN FS, DONG F, MILLER TR, YEO PP. Influence of lymphocytic thyroiditis on the prognostic outcome of patients with papillary thyroid carcinoma. J Clin Endocrinol Metab 1999; 84: 458-463. https://doi.org/10.1210/ jcem.84.2.5443

[31] LEE JH, KIM Y, CHOI JW, KIM YS. The association between papillary thyroid carcinoma and histologically proven Hashimoto's thyroiditis: a meta-analysis. Eur J Endocrinol 2013; 168: 343-349. https://doi.org/10.1530/EJE-12-0903

[32] MAROTTA V, GUERRA A, ZATELLI M C, UBERTI E D, DI STASI $V$ et al. BRAF mutation positive papillary thyroid carcinoma is less advanced when Hashimoto's thyroiditis lymphocytic infiltration is present. Clin Endocrinol (Oxf) 2013; 79: 733-738. https://doi.org/10.1111/cen.12194

[33] BALOCH ZW, LIVOLSI VA. Current role and value of fineneedle aspiration in nodular goitre. Best Pract Res Clin Endocrinol Metab 2014; 28: 531-544. https://doi.org/10.1016/j. beem.2014.01.010

[34] LIU R, NING L, LIU X, ZHANG H, YU Y et al. Association between single nucleotide variants of vascular endothelial growth factor a and the risk of thyroid carcinoma and nodular goiter in a Han Chinese population. Oncotarget 2017; 8: 15838-15845. http://doi.org/10.18632/oncotarget.15028 